\title{
INSIDENSI PENGGEREK BATANG PADI KUNING (Schirpophaga incertulas Walker) PADA TIGA VARIETAS PADI : KASUS DI DESA KEMUMU BENGKULU UTARA
}

\author{
Irma Cahyoko ${ }^{1}$, Dwinardi Apriyanto ${ }^{2 *}$, Kanang S. Hindarto ${ }^{1}$ \\ ${ }^{1}$ Program Studi Agroekoteknologi, Fakultas Pertanian, Universitas Bengkulu \\ ${ }^{2}$ Program Studi Proteksi Tanaman, Fakultas Pertanian, Universitas Bengkulu \\ Corresponding Author :kang_dwi@unib.ac.id
}

\begin{abstract}
[INCIDENCE OF THE RICE YELLOW STEM BORER (Schirpophaga incertulas Walker) ON THREE RICE VARIETIES IN KEMUMU, NORTH BENGKULU]. Rice yellow stem borer (RYSB), Schirpophaga incertulas Walker, often causes yield loss in irrigated rice field. Dead heard and white ear head are the common symptomps resulted from the larval damage. The use of resistant varieties may reduce the risk of yield loss, but the resistance may lose quickly as the varieties are continually grown in a large area. The assessment of the insect incidence in rice field is necessary in order to determine the status of the pest for certain period of time. The objective of the study was to determine the incidence and damage incurred by RYSB in three rice varieties, Mekongga, Cibogo, and Situ Bagendit at farmer rice fields. A survey was conducted in December 2017-February 2018 in Kemumu, North Bengkulu Regency. Observation of RYSB was made on randomly selected 30 hills from \pm 1 ha area for each variety that was located adjacent to each other. Grain yield was measured from the sampled hills and from 3 plots of $9 \mathrm{~m}^{2}$. Weight of 1000 grain was measured from grain of three sampled hills. The results revealed that the incidence of RYSB was low, as indicated by the presence of egg mass and larvae of RYSB, and no significant difference was found among the three varieties. Nevertheless, the average cumulative number and percentage of dead heart and white ear head was significantly lower in Mekongga than those of Cibogo and Situ Bagendit. In term of grain yield, however, Mekongga outperformed the other two varieties. The low incidence of RYSB might suggest that growing different variety practiced by local farmers was able to suppress pest population, and therefore it should be implemented in all main areas of rice production.
\end{abstract}

Keyword: rice varieties, rice yellow stem borer, dead heart, white ear head, yield loss

\begin{abstract}
ABSTRAK
Penggerek batang padi kuning (PBPK), Schirpophaga incertulas Walker, sering menyebabkan kehilangan hasil padi sawah. Penggunaan varietas tahan terhadap PBPK dapat mengurangi resiko kehilangan hasil dan kegagalan panen, akan tetapi bila varietas tersebut ditanam secara terus-menerus dalam hamparan yang luas, sifat ketahanan akan hilang dengan cepat. Penilaian insidensi hama pada sentra padi diperlukan untuk mengetahui status hama dalam rentang waktu tertentu. Tujuan penelitian adalah untuk mengukur insidensi PBPK dan hasil dari tiga varietas padi, Mekongga, Cibogo dan Situ Begendit yang ditanam di sawah milik petani. Survei dilakukan pada bulan Desember 2016 - Februari 2017 di Desa Kemumu, Kabupaten Bengkulu Utara. Pengamatan PBPK dilakukan terhadap 30 rumpun yang ditetapkan secara acak dari tiap varietas pada area seluas \pm 1 ha yang lokasinya saling berdekatan. Hasil gabah diukur dari 10 rumpun sampel dan dari 3 ubinan ukuran $9 \mathrm{~m}^{2}$. Bobot 1000 butir gabah diamati dari tiga rumpun yang sampel. Hasil penelitian menunjukkan bahwa tingkat serangan PBPK termasuk rendah sebagaimana tercermin dari jumlah kelompok telur dan larva per rumpun yang berbeda tidak nyata antar varietas. Meskipun demikian, Mekongga memiliki rata-rata kumulatif jumlah dan persen sundep dan beluk nyata lebih rendah dibandingkan pada Cibogo dan Situ Bagendit. Demikian juga, Mekongga memiliki hasil gabah secara nyata lebih tinggi dibandingkan kedua varietas tersebut. Insidensi hama yang rendah menunjukkan bahwa pola tanam yang dilakukan petani dengan menganekaragamkan varietas mampu menekan populasi hama di lapangan dan pola seperti ini sebaiknya diterapkan di semua sentra produksi padi.
\end{abstract}

Kata kunci: varietas padi, penggerek batang padi kuning, sundep, beluk, kehilangan hasil 


\section{PENDAHULUAN}

Penggerek batang padi kuning (PBPK), Schirpophaga incertulas Walker, merupakan salah satu hama terpenting dari lima jenis pengerek yang ada di Asia. Hama ini tersebar luas di negara-negara penghasil padi di Asia yang bisa menyebabkan kerusakan serius pada tanaman padi sawah dan lebak sejak dari persemaian sampai menjelang panen. Kehadiran hama tersebut di lapangan menyebabkan kerusakan pada anakan tanaman padi, yang populer disebut sundep (dead heart) pada fase vegetatif dan beluk (white ear head) pada fase generatif (Baehaki, 2009; 2015). Sundep dan beluk adalah matinya bagian tanaman yang pangkal barangya putus karena digerek larva penggerek batang. Sundep terbentuk dari daun yang belum membuka mati, sedangkan beluk terbentuk dari tangkai dan malai yang mati dan gabahnya belum terisi.

Insidensi PBPK selalu dilaporkan di beberapa wilayah di Indonesia lebih sering dan dominan dibandingkan dengan penggerek batang lainnya (Baehaki, 2015; Hadi et al. 2015; Aryantini et al., 2015; Kakde \& Patel, 2014). Kehilangan hasil akibat serangan hama ini menjadi hambatan dalam program peningkatan produksi pangan nasional. Meningkatnya permasalahan hama sudah difahami pada level peneliti terjadi sebagai akibat dari penyederhanaan ekosistem pertanian secara luas. Pencerahan pada level petani tentang peran musuh alami dalam pengendalian hama padi terjadi ketika Indonesia menerapkan pengelolaan hama terpadu melalui Program Sekolah Lapang Pengelolaan Hama Terpadu (SLPHT), akan tetapi saat ini banyak petani meninggalkan pengetahuan tersebut.

Penggunaan insektisida untuk mengendalikan hama-hama padi menurun drastik sejak keberhasilan SLPHT, dan fenomena itu bukan hanya perubahan ke arah pengelolaan hama yang ramah lingkungan, akan tetapi juga ke arah penggunaan masukan (input) yang lebih hemat (ekonomis) (Mariyono \& Irham, 2001). Akan tetapi, saat ini insektisida kembali menjadi andalan petani untuk mengendalikan hama padi, dan kecenderungannya meningkat, kembali mengulang pola pengendalian hama sebelum Indonesia sukses dengan program SLPHT (Tornburn, 2015). Hal ini harus menjadi perhatian serius pemerintah, peneliti dan penyuluh pertanian, karena penggunaan pestisida secara tidak bijaksana yang semula menjadi andalan untuk mengatasi masalah hama berdampak samping yang merusak lingkungan (Cantrell \& Hettel, 2004) dan ini banyak dilaporkan terjadi di banyak negara, termasuk Indonesia. Bila penggunaan pestisida cenderung terus meningkat maka akan menghambat upaya peningkatan produksi dan kedaulatan pangan. Oleh sebab itu apabila insektisida terpaksa harus menjadi komponen pengelolaan hama, sebaiknya dikombinasikan dengan teknologi yang kompatibel, misalnya penggunaan varietas tahan hama dan mengutamakan rekayasa lingkungan untuk meningkatkan peran musuh alami dalam pengendalian alami. Pada prinsipnya aplikasi insektisida ketika tanaman padi masih di persemaian dan 1-2 kali pada fase vegetatif dapat memberikan hasil yang memuaskan. Hasil penelitian menunjukkan bahwa resiko kehilangan hasil tinggi; bila pada awal pertumbuhan tidak ada intervensi pengendalian, resiko kehilangan hasil bisa mencapai $>80 \%$ (Pallavi et al., 2017).

Rekayasa lingkungan dengan cara meningkatkan keanekaragaman spesies vegetasi bisa menjadi model terbaik dalam upaya pengelolaan populasi hama baik dalam skala lansekap makro (Buchori \& Sahari, 2008; Gurr et al. 2017), maupun skala lansekap mikro (Zhao et al., 2013; Bennetti \& Gratton, 2013), tetapi Scherber et al. (2006), menyimpukan bahwa identitas kelompok fungsional kelompok spesies tanaman lebih penting dibandingkan kekayaan spesies itu sendiri. Varietas tahan bisa menjadi alternatif terbaik dengan potensi imbalan ekonomi yang paling menjanjikan untuk menekan kerusakan tanaman padi di lahan sawah akibat serangan penggerek batang padi, karena bisa mengurangi penggunaan insektisida dan akumulasi penurunan populasi hama (Rubia et al., 1989).

Varietas resisten bila ditanam terus menerus di area yang sama sifat tahan akan kehilangan kemampuan untuk menghambat peningkatan populasi hama sasaran, terutama pada serangga hama yang kisaran inangnya terbatas (Gethouse, 2002). Agar varietas tahan bertahan lebih lama, perlu dilakukan pengkayaan dan rotasi varietas. Oleh karena itu informasi tentang status ketahanan suatu varietas di lokasi tertentu sangat diperlukan, terutama untuk melihat apakah varietas bersangkutan merupakan varietas yang masih bisa dipertahankan di suatu daerah sentra tanaman padi. Ketersediaan informasi insidensi PBPK dan hama lain dengan pola pengelolaan hama yang dilakukan petani setempat sangat jarang di Bengkulu. Informasi tersebut sangat diperlukan untuk antisipasi pengendalian apabila terjadi kecenderungan peningkatan populasi atau kerusakan tanaman padi. Pada penelitian ini disajikan data insidensi PBPK dan dampak kerusakan yang ditimbulkan pada tiga varietas yang ditanam petani.

\section{METODE PENELITIAN}

Penelitian ini dilakukan pada bulan Desember 2016 sampai Februari 2017 dengan metode survei di lahan persawahan Desa Kemumu, Kecamatan Arma Jaya 
Kabupaten Bengkulu Utara, pada ketinggian tempat 400 $\mathrm{m}$ dpl. Pengamatan PBPK dilakukan pada sawah milik petani dengan varietas yang berbeda, Mekongga, Cibogo dan Situ Bagendit, yang lokasinya berdekatan. Menanam beberapa varietas yang berbeda dalam satu musim sudah biasa dilakukan oleh para petani di Desa Kemumu dan sekitarnya. Petani juga sering mengganti (merotasi) varietas pada musim tanam berbeda.

Input pupuk yang dilakukan yaitu dengan Urea (50 kg/ha), Posca; NPK 15-15-15 (100 kg/ha), dan SP $36(75 \mathrm{~kg} / \mathrm{ha})$. Penyiangan dilakukan sebanyak dua kali pada umur 35 hari setelah tanam (hst) dan 45 hst. Pengendalian hama dilakukan pada musim berjalan dan pada musim sebelumnya menggunakan Insektisida Klensect 200 EC (b.a. Permetrin) pada konsentrasi 6\% (0,6 mL/10 L air) dan Dangke $40 \mathrm{WP}$ (b.a Metomil), pada konsentrasi $4 \mathrm{~g} / \mathrm{L}$ air, dilakukan sebanyak tiga kali pada 15 hst, 30 hst, dan 40 hst.

Sampel tanaman (rumpun) padi pada masingmasing petak pengamatan $( \pm 1$ ha untuk masingmasing varietas) ditentukan secara acak pada garis yang kurang lebih diagonal. Sampel yang diamati berjumlah 30 rumpun per petak pengamatan. Pengamatan dilakukan secara langsung di lapangan sekali seminggu, dimulai pada saat tanaman berumur \pm 1 bulan dalam masa pertumbuhan.

Anakan tanaman padi yang terserang PBPK yang menunjukkan gejala sundep dan beluk dan anakan sehat pada setiap rumpun sampel dihitung dan dicatat jumlahnya. Semua rumpun sampel diamati dengan teliti dan bila ditemukan kelompok telur dan larva neonat (larva yang baru keluar dari telur) dihitung dan dicatat jumlahnya. Anakan yang menunjukkan gejala sundep dan beluk diambil, dimasukkan ke dalam kantong plastik $1 / 2 \mathrm{~kg}$, diberi label nomor sampel, varietas dan tanggal pengamatan, dan selanjutnya dibawa ke Laboratorium Proteksi Tanaman, Universitas Bengkulu untuk diperiksa lebih lanjut keberadaan larva dan pupa PBPK.

Untuk mengetahui dampak insidensi PBPK pada hasil, sampel rumpun sebanyak 30 dipanen bersamaan dengan waktu panen yang dilakukan petani. Sampel panen gabah juga diambil dari petak ubinan seluas $9 \mathrm{~m}^{2}$ sebanyak tiga ulangan per varietas. Gabah dari sampel rumpun dan ubinan masing-masing ditimbang segera setelah dipanen untuk mendapatkan bobot kering panen. Data yang diperoleh dari hasil penelitian dianalisis dengan menggunakan analisis varian (ANAVA) dan dilanjutkan dengan uji Beda Nyata Terkecil (BNT) dengan menggunakan Program Sx.versi 10.

\section{HASIL DAN PEMBAHASAN}

Secara umum tingkat kerusakan (sundep dan beluk) dan kelimpahan PBPK masih termasuk rendah dan cenderung menurun dari pengamatan pertama (tanaman berumur 30 hst sampai pengamatan terakhir (tanaman berumur $107 \mathrm{hst}$ ) (Gambar 1). Rata-rata persentase anakan terserang PBPK per rumpun tertinggi terjadi pada pengamatan pertama ketika tanaman berumur 30 hst (saat pembentukan anakan) dan selanjutnya berfluktuasi namun cenderung menurun hingga pengamatan terakhir ketika tanaman berumur 107 hst. Insidensi PBPK tersebut lebih rendah dibandingkan dengan yang dilaporkan oleh Kakde \& Patel (2014) di India. Mereka juga melaporkan bahwa isidensi PBPK masih mengalami peningkatan sampai bulan ke tiga.

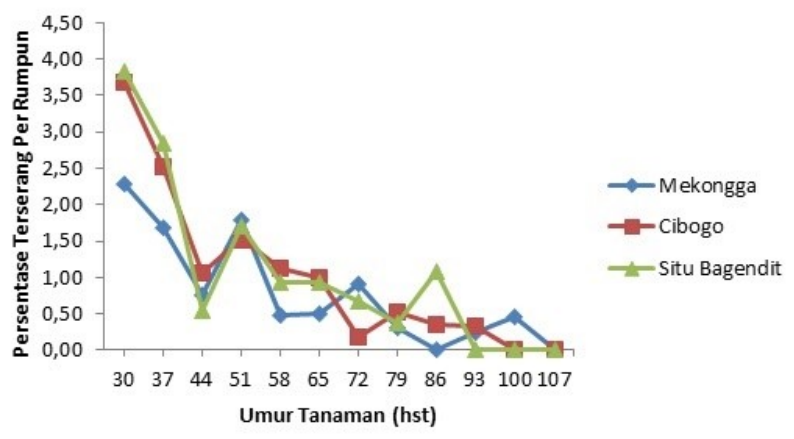

Gambar 1.Fluktuasi rata- rata persentase serangan penggerek batang padi kuning (PBPK) Scirpophaga incertulas Walker pada tiga varietas tanaman padi pada musim tanam Desember 2016-Maret 2017 di Desa Kemumu, Kabupaten Bengkulu Utara

Populasi larva PBPK pada penelitian ini jauh lebih rendah dibandingkan dengan yang dilaporkan oleh Damayanti et al. (2015) di Banyuwangi Jawa Timur, baik data dari plot pengenlolaan hama terpadu (PHT) maupun plot dengan pengendalian hama sistem konvensional dengan aplikasi insektisida sebanyak enam kali. Insidensi PBPK tersebut juga lebih rendah bila dibadingkan dengan ambang pengendalian penggerek batang padi yang diukur dari tingkat kerusakan (persen anakan produktif terserang) sebesar 5\% pada fase vegetatif dan $9 \%$ pada fase generatif (Baehaki et al. 2002). Tingkat kerusakan tertinggi $(3,8 \%)$ terjadi ketika tanaman berumur $30 \mathrm{hst}$ ), namun terus menurun pada fase 


\section{CAHYOKO et al.}

pertumbuhan berikutnya. Rata-rata jumlah sundep dan beluk yang dijumpai pada Mekongga lebih rendah dibandingakan dengan dua varietas yang lain.

Fluktuasi tingkat serangan PBPK sangat sinkron dengan fluktuasi jumlah larva seiring dengan pertumbuhan tanaman. Jumlah telur secara umum mengalami peningkatan pada pengamatan ke 5-6 (tanaman berumur 51-86 hst) (Gambar 2). Namun, peningkatan jumlah kelompok telur tersebut tidak diikuti dengan peningkatan jumlah larva (Gambar 3). Kedua fenomena tersebut menunjukkan bahwa telur yang terbentuk tidak seluruhnya berhasil menetas menjadi larva. Hasil penelitian Chakraborty \& Nandi (2009) menunjukkan bahwa populasi telur berkorelasi negatif dengan rata-rata curah hujan. Mortalitas pada fase telur dapat juga disebabkan oleh parasitoid telur dan predator atau faktor lain, atau terjadi pada saat larva neonat yang belum sempat masuk ke batang karena berbagai faktor fisik, biologi (predator) maupun kimia (insektisida). Banyak spesies Hymenoptera dilaporkan sebagai parasitoid telur PBPK, termasuk Chelonus rowani dan Chelonus dictus, sebagaimana dilaporkan oleh Buchori et al. (2008). Rendahnya tingkat serangan PBPK di lokasi penelitian dapat juga terjadi karena berbagai faktor alami maupun karena intervensi pengendalian dengan insektisida yang dilakukan sebanyak 3 kali.

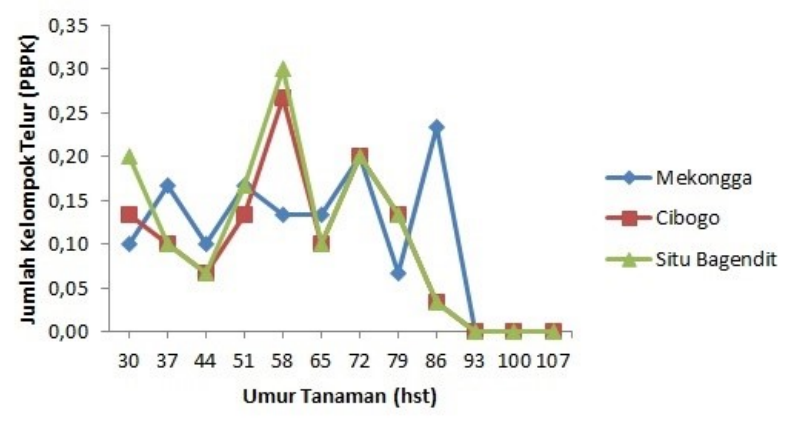

Gambar 2.Fluktuasi rata-rata jumlah kelompok telur penggerek batang padi kuning (PBPK) Scirpophaga incertulas Walker pada tiga varietas tanaman padi pada musim tanam Desember 2016Maret 2017 di Desa Kemumu, Kabupaten Bengkulu Utara

Analisis keragaman menunjukkan perbedaan yang sangat nyata antar varietas untuk jumlah dan persentase anakan terserang PBPK (sundep dan beluk). Mekongga menunjukkan tingkat kerusakan yang lebih rendah dibanding kedua varietas lainnya (Tabel 1). Dalam deskripsi BBPTP (2010) dinyatakan bahwa varietas Cibogo sangat peka terhadap hama PBPK sedangkan varietas Mekongga cukup tahan terhadap hama yang sama. Ketahanan Mekongga lebih tinggi dibandingkan dengan dua varietas yang lain. Meskipun demikian, fenomena antixenosis tidak dijumpai pada ketiga varietas yang ditanam pada jarak yang berdekatan satu sama yang lain, sebagaimana ditunjukkan oleh jumlah telur dan larva PBPK. Hasil analisis keragaman terhadap kedua variabel tersebut menunjukkan perbedaan yang tidak nyata.

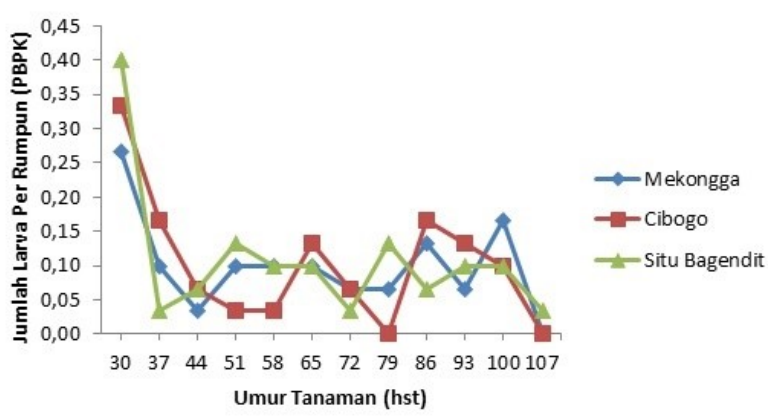

Gambar 3.Fluktuasi rata-rata jumlah larva penggerek batang padi kuning (PBPK) Scirpophaga incertulas Walker pada tiga varietas tanaman padi pada musim tanam Desember 2016-Maret 2017 di Desa Kemumu, Kabupaten Bengkulu Utara

Tabel 1. Rerata jumlah kelompok telur, jumlah larva per rumpun dan jumlah anakan terserang penggerek batang padi kuning (PBPK) pada varietas Mekongga, Cibogo dan Situ Bagendit ${ }^{1)}$

\begin{tabular}{lcccc}
\hline Varietas & $\begin{array}{c}\text { Jumlah kelompok } \\
\text { telur per rumpun }\end{array}$ & $\begin{array}{c}\text { Jumla larva } \\
\text { per rumpun }\end{array}$ & $\begin{array}{c}\text { Jumlah anakan } \\
\text { terserang PBPK }\end{array}$ & $\begin{array}{c}\text { Persentase } \\
\text { serangan }\end{array}$ \\
\hline Mekongga & $1,0 \mathrm{a}$ & $1,1 \mathrm{a}$ & $1,8 \mathrm{~b}$ & $7,58 \mathrm{~b}$ \\
Cibogo & $1,1 \mathrm{a}$ & $1,2 \mathrm{a}$ & $2,3 \mathrm{a}$ & $14,10 \mathrm{a}$ \\
Situ Bagendit & $1,2 \mathrm{a}$ & $1,2 \mathrm{a}$ & $2,2 \mathrm{a}$ & $10,52 \mathrm{ab}$ \\
\hline 1) Rerata varietas yang dikuti huruf yang sama berbeda tidak nyata (Uji BNT; $\mathrm{\alpha}=0,05)$. &
\end{tabular}

Tabel 2. Rerata hasil panen per rumpun dan hasil ubinan varietas Mekongga, Cibogo dan Situ Bagendit ${ }^{1)}$

\begin{tabular}{lccc}
\hline Varietas & $\begin{array}{c}\text { Bobot GKP } \\
\text { per rumpun }(\mathrm{g})\end{array}$ & $\begin{array}{c}\text { Persentase } \\
\text { serangan }\end{array}$ & $\begin{array}{c}\text { Ubinan GKP } \\
(\mathrm{kg})\end{array}$ \\
\hline Mekongga & $54,6 \mathrm{a}$ & $7,58 \mathrm{~b}$ & $7,13 \mathrm{a}$ \\
Cibogo & $45,7 \mathrm{~b}$ & $14,10 \mathrm{a}$ & $6,79 \mathrm{~b}$ \\
Situ Bagendit & $43,9 \mathrm{~b}$ & $10,52 \mathrm{ab}$ & $6,66 \mathrm{~b}$ \\
\hline 1) Rerata varietas yang dikut huruf yang sama berbeda tidak nyata (Uji BNT; $\alpha=0,05)$. &
\end{tabular}

Dalam analisis keragaman, perbedaan sangat nyata antar varietas dijumpai pada bobot GKP per rumpun maupun per ubin. Berdasarkan nilai rataratanya, Mekongga menunjukkan hasil gabah yang lebih tinggi dibanding kedua varietas lainnya (Tabel 2). Produktifitas varietas Mekongga lebih tinggi dibandingkan dengan dua varietas yang lain. Pada penelitian ini tidak bisa dipisahkan antara karakter produkstifitas dengan karakter ketahanan terhadap penggerek batang padi yang datanya juga menunjukkan bahwa varietas mekongga termasuk varietas agak tahan, sesuai dengan deskripsi varietas. Variabilitas resistensi varietas padi terhadap penggerak batang juga dilaporkan oleh Subhashrao (2009) di Gujarat India.

Secara umum insidensi PBPK masih termasuk rendah. Sebagaimana sudah dijelaskan sebelumnya, rendahnya insidensi atau kelimpahan PBPK ini 
mungkin merupakan hasil dari penganekaragaman varietas padi dalam ruang (pada musim tanam yang sama) dan dalam waktu (rotasi varietas) dan aplikasi insektisida sebanyak 3 kali yang dilakukan petani setempat. Pallavi et al. (2017) melaporkan hasil penelitian mereka bahwa aplikasi insektisida pada persemaian umur 15 hari diikuti dengan aplikasi pada awal pertumbuhan (tanaman umur 15 dan 30 hari mampu menekan kerusakan tanaman oleh PBPK.

Meskipun belum ada penelitian di sekosistem persawahan di Kemumu, rendahnya kelimpahan PBPK dapat terjadi karena "jasa pengendalian" yang dilakukan oleh musuh alami, terutama parasitoid telur. Kehadiran parasitoid telur pada PBPK sudah banyak dilaporkan oleh banyak peneliti, termasuk di Bengkulu (Buchori et al. 2008). Kelimpahan populasi hama yang tinggi sering disebabkan oleh penyederhanaan ekosistem, misalnya dalam hamparan (lansekap) yang luas didominasi oleh satu jenis tanaman, sebagaimana yang dilporkan oleh Buchori et al. (2008) yang membandingkan ekosistem sawah di daerah Subang yang monokultur padi pada area yang luas dengan ekosistem persawahan di sekitar Taman Nasional Gunung Halimun dengan berbagai tanaman dan tumbuhan berkayu di lahan kering, pekarangan dan hutan. Pembahasan senada banyak dilakukan oleh peneliti lain (Tscharntke et al. 2016, Gurr et al 2017, lihat Landis 2017) dengan kesimpulan yang kurang lebih sama, kelimpahan hama lebih rendah dan kelimpahan musuh alami lebih tinggi pada lansekap dengan keanekaragaman vegtasi yang tinggi. Berbagai kajian publikasi ilmiah yang membahas pengelolaan habitat memperkuat landasan teori bahwa manipulasi habitat dengan cara meningkatkat kenekaragaman vegetasi dalam skala lansekap secara positif meningkatkan peran komunitas musuh alami hama dan mengurangi insidensi berbagai hama pada ekosistem pertanian (Gurr et al. 2017).

Ekosistem persawahan di Desa Kemumu, Bengkulu Utara sangat berbeda dengan ekosistem persawahan di daerah lain (misalnya pantai utara Jawa) yang membentuk ekosistem monokultur tanaman padi pada area yang sangat luas. Ekosistem persawahan Desa Kemumu mempunyai keanekaragaman vegatasi yang tinggi dengan adanya perkampungan dengan berbagai tanaman tahunan di pekarangan dan lahan kering serta hutan lindung. Keberadaan berbagai jenis pohon dan berbagai tumbuhan non-budidaya membentuk habitat yang lebih menyerupai ekosistem agroforestry yang sangat kompleks. Keberlajutan budidaya tenaman dewasa ini sering dikaitkan dengan usaha menganekargamkan ekosistem pettanian dengan tujuan terutama untuk meningkatkan kelimpahan musuh alami dan menghindari kerusakan tanaman akibat kelimpahan yang tinggi dari hama.

Di berbagai sentra padi di Indonesia, sebagian petani masih menggunakan pestisida tanpa pertimbangan atau pedoman kelimpahan hama sama sekali, sebagaimana yang dilakukan petani di Desa Kemumu, Bengkulu Utara. Penggunaan pestisida mungkin hanya diperlukan pada awal pertumbuhan padi atau sama sekali tidak diperlukan bila petani melakukan monitoring kelimpahan atau insidensi hama. Bila rekayasa ekosistem untuk meningkatkan kompleksitas habitat, termasuk menanam multivarietas dan rotasi varietas dalam skala lansekap seperti yang dilakukan petani setempat mampu mengatasi permasalahan hama, termasuk PBPK, maka penggunaan pestisida secara rutin tidak diperlukan lagi atau dapat dikurangi.

\section{KESIMPULAN}

Tingkat serangan PBPK di Desa Kemumu Bengkulu Utara termasuk rendah. Insidensi PBPK berbeda tidak nyata pada ketiga varietas, akan tetapi menimbulkan kerusakan anakan nyata lebih tinggi pada varietas Cibogo dibandingkan dengan Mekongga dan Situ Bagendit. Varietas Mekongga mengalami kerusakan paling rendah sesuai dengan deskripsi varietas ini yang disebutkan sebagai agak tahan terhadap PBPK. Insidensi dan kerusakan tanaman oleh hama yang rendah kemungkinan merupakan dampak positif dari pola tanam multi- dan rotasi-varietas yang dilakukan oleh petani dalam hamparan sawah yang cukup luas dan keberagaman ekosistem setempat. Pola tanam seperti itu sebaiknya dipertahankan terus dan disebarkan ke daerah lain yang masih sering menghadapi masalah serangan hama. Hasil panen tertinggi terdapat pada varietas Mekongga yang ditunjang oleh berbagai veriabel pertumbuhan tanaman dan pengukuran produksi yang lebih tinggi pada varietas Mekongga merupakan resultante dari berbagai keunggulan agronomi dan ketahanan terhadap hama, serta kontribusi dari keanekaragaman varietas dan ekosistem setempat.

\section{DAFTAR PUSTAKA}

Aryantini, L., Supartha, I. W. \& Wijaya, I. N. (2015). Kelimpahan populasi dan serangan penggerek batang padi pada tanaman padi di Kabupaten Tabanan. Agroteknologi Tropika, 4(3), 203-212.

Baehaki S.E., Baskoro, \& Rifki, A. (2002). Assessment of multiple economic threshold of rice pests on different rice varieties. International Rice Congress. 16-20 September 2002. Beijing, China. $15 \mathrm{p}$.

Baehaki, S.E. (2009). Strategi pengendalian hama terpadu tanaman padi dalam perspektif praktek pertanian yang baik (good agricultural practices). Pengembangan Inovasi Pertanian, 2 (1), 65-78. 


\section{CAHYOKO et al.}

Baehaki, S. E. (2015). Hama penggerek batang padi dan teknologi pengendalian. Iptek Tanaman Pangan, 8(1), 1-14.

BBPTP. (2010). Deskripsi Varietas Padi. BBTP. Sukamandi.

Bennett, A. B., \& Gratton, C. (2013). Floral diversity increases beneficial arthropod richness and decreases variability in arthropod community composition. Ecological Applications, 23(1), 86 -95 .

Buchori, D., Sahari, B. \& Nurindah. (2008). Conservation of agroecosystem through utilization of parasitoid diversity: Lesson for promoting sustainable agriculture and ecosystem health. HAYATI Journal of Biosciences, 15(4), 165-172.

Cantrell, R.P. \& Hettel, G.P. (2004). The Doubly Green Revolution in Rice. Paper presentation at the World Food Prize Symposium: Rice, Biofortification, and Enhanced Nutrition, Des Moines, Iowa, 14-15 October 2004.

Chakraborty, K. \& Nandi, P.S. (2009). Incidence of Paddy yellow stem borer (Scirpophaga incertulas, WALKER) in relation to the agro climatic region of Hemtabad, Uttar.Dinajpur, West Bengal, India. International Referred Research Journal 2 (19): 48-49.

Damayanti, E., Mudjiono, G. \& Karindah, S. (2015). Perkembangan populasi larva penggerek batang dan musuh alaminya pada tanaman padi (Oryza sativa L.) PHT. Jurnal Hama dan Penyakit Tumbuhan, 3(2), 18-24.

Gatehouse, J. A. (2002). Plant resistance towards insect herbivores: a dynamic interaction. New phytologist, 156(2), 145-169. https://doi.org/ 10.1046/j.1469-8137.2002.00519.x.

Gurr, G. M., Wratten, S. D., Landis, D. A. \& You, M. (2017). Habitat management to suppress pest populations: progress and prospects. Annual review of entomology, 62, 91-109.

Hadi, M., Soesilohadi, R. H., Wagiman, F. X. \& Soehardjono, Y. R. (2015). Populasi penggerek batang padi pada ekosistem sawah organik dan sawah anorganik. Bioma: Berkala Ilmiah Biologi, 17(2), 106-117.

Kakde, A. M., \& Patel, K. G. (2014). Seasonal Incidence of rice yellow stem borer (Scirpophaga incertulas Wlk.) in relation to conventional and sri methods of planting and its correlation with weather parameters. Journal of Agriculture and Veterinary Science, 7(6), 05-10.

Landis, D. A. (2017). Designing agricultural landscapes for biodiversity-based ecosystem services. Basic and Applied Ecology, 18, 1-12.

Mariyono, J., \& Irham, I. (2001). Usaha menurunkan penggunaan pestisida kimia dengan program pengendalian hama terpadu. Jurnal Manusia dan Lingkungan, 8(1), 30-36.

Pallavi, D., Sharanabasappa \& Girijesh, G.K. (2017). Crop loss estimation of yellow stem borer Scirpophaga incertulas (Walker) damage on paddy. J. Entomol. and Zool. Studies 5(6), 635638.

Rubia, E. G., Shepard, B. M., Yambao, E. B., Ingram, K. T., Arida, G.S. \& Penning, D. V. (1989). Stem borer damage and grain yield of flooded rice. Journal of Plant Protection in the Tropics, 6(3), 205-211.

Scherber, C., Mwangi, P. N., Temperton, V. M., Roscher, C., Schumacher, J., Schmid, B. \& Weisser, W. W. (2006). Effects of plant diversity on invertebrate herbivory in experimental grassland. Oecologia, 147(3), 489-500. https:// doi.org/10.1007/s00442-005-0281-3.

Subhashrao, D. S. (2009). Bioecology and Management of Yellow Stem Borer Scirpophaga incertulas (Walker) Infesting Paddy, Oryza sativa (L.) Under Middle Gujarat Conditions (Doctoral dissertation), Anand Agricultural University, Anand.

Thorburn, C. (2015). The rise and demise of integrated pest management in rice in Indonesia. Insects, 6(2), 381-408. https://doi.org/ 10.3390/insects6020381.

Tscharntke, T., Karp, D. S., Chaplin-Kramer, R., Batáry, P., DeClerck, F., Gratton, C. \& Martin, E. A. (2016). When natural habitat fails to enhance biological pest control-Five hypotheses. Biological Conservation, 204, 449-458. https://dx.doi.org/ 10.1016/j.biocon.2016.10.001.

Zhao, Z., Shi, P., Men, X., Ouyang, F. \& Ge, F. (2013). Effects of crop species richness on pestnatural enemy systems based on an experimental model system using a microlandscape. Science China Life Sciences, 56(8), 758-766. https:// doi.org/10.1007/s11427-013-4511-3. 